\title{
OonOMic
}

Ibrahim A. Onour

\section{The impact of COVID-19 pandemic shock on major Asian stock markets: evidence of decoupling effects}

\section{KEYWORDS}

COVID-19;

Markov switching;

Asia;

stock markets

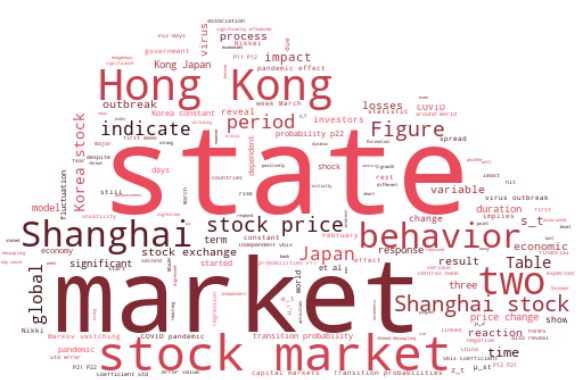

Word Cloud Generated by:

https://wordscloud.pythonanywhere.com/

\section{ABSTRACT}

Introduction. Despite the start of the outbreak of the virus (COVID-19) was in December 2019, stock markets did not respond immediately as there was little information about the expected duration of the crisis and whether China would be able to contain it within a short period of time, and the risks entailing to the global economy due to the virus spread becoming pandemic that endanger the global health situation. As a result of the great uncertainty that prevailed among investors in the third week of February, stock markets around the world incurred trillions of US dollars in losses in a single week (ending February) seen as the worst week for financial markets since the 2008 global financial crisis. The initial purpose of this paper is to assess the reaction of major Asian stock markets to the early outbreak of COVID-19 pandemic and its spillover effects among these markets.

Material and methods. To capture switching behavior of major Asian stock markets due to the early outbreak of COVID-19, the paper uses daily price indexes of Shanghai composite, Hong Kong, Nikkei 225, and Korea stock market, during the period from December 2, 2019 to March, 13,2020. Markov switching dynamic regression (MSDR) employed to assess the behavior of each market to the response of the other markets' behavior.

Results. Our finding indicate evidence of two states that distinguish the behavior of the stock markets during the early outbreak of the pandemic. In state 1, when the significance of the pandemic was not fully realized there was a strong link and influence between these markets, but in state 2, when the scale and size of the pandemic realized these markets displayed decoupling behavior. Results also indicate, Hong Kong and Nikkie stock markets were the epicenter in both states. The impact of the pandemic news on the behavior of these markets as indicated by the transition probabilities of state 2, varied from 3 days duration effect (Hong Kong) to 3month duration effect (Nikkei 225).

Discussion and conclusions. The interactive association between these stock markets is important for investors as well as for policymakers. Increasing departure of stock prices from their fundamental driver, that is the common economic bonds linking these markets, implies increasing risk for investors in these stock markets. The duration of the shock as indicated by the transition probabilities show that Hong Kong stock exchange was the most resilient in the group, while Nikkei was the most reactive to the pandemic shock.

Onour, I. A. (2021). The impact of covid-19 pandemic shock on major Asian stock markets: evidence of decoupling effects. Economic consultant, 34 (2), 21-32. doi: 10.46224/ecoc.2021.2.3 


\section{INTRODUCTION}

$\mathrm{T}$

he fast expansion of the coronavirus COVID-19, around the globe, nearly 200,000 infections in about 120 countries by Februry 4, have spread fear around the globe and disrupted the world economic activities, including capital markets, the nerve of the world economy. Despite the start of the outbreak of the virus (COVID-19) was in December 2019, stock markets did not respond immediately as there was little information about the expected duration of the crisis and whether China would be able to contain it within a short period of time, and the risks entailing to the global economy due to the virus spread and becoming pandemic that endanger the global health situation. As a result of the great uncertainty that prevailed among investors in the third week of February, stock markets around the world incurred trillions of US dollars in losses in a single week (ending February) seen as the worst week for financial markets since the 2008 global financial crisis. On this week China's Shenzhen stocks incurred losses among major markets regionally as they closed sharply lower, followed by Nikkei 225, and then Hong Kong's Hang Seng. On the first week of March due to stimulus measures declared by central banks, some of these markets rebounded and gained earnings that erased the previous week's losses, but very soon again hit by another big losses. Central banks stabilization policies around the world took different directions in their attempt to avail the needed fiscal and monetary policy support. While the US Federal Reserve bank cut the interest rate to 1\%. The European Central Bank, Bank of Japan and Bank of England announced readiness to respond to any negative impacts caused by the pandemic to safeguard financial stability of their markets. Chinese government approved 500 billion yuan ( $\$ 71$ billion) loans with low interest rates to small enterprises affected by the impact of the pandemic. However, all these moves by the central banks and governments to reassure investors around the world did little to calm fears, as financial markets resumed again their slide down after March second. To date, the virus outbreak is still expanding and causing global chaos that may disrupt economic activities in many countries around the world $[16 ; 17 ; 18]$. Till now, nobody knows how long will last the uncertainty hanging over the world economy [19]. Unfortunately, the feared biggest problem ahead, is shrink of global economic growth. The OECD has already warned that continuation of the outbreak could cut global GDP growth to $1.5 \%$, sending a number of major economies into recession.

It is well documented in the literature that the effect of unexpected shocks to the real economy passes through stock markets. As stock markets fall, household wealth shrink and their saving increases leading into consumption decrease and then into economic depression. Such a negative impact expected to be very significant in the economies where individual households are highly connected with equity markets. COVID-19 seems potentially strong hit on global stock markets as investors became pessimistic about the repeated lockdowns of all activities [15]. Empirical research [1] documented that pandemics cause fear and panic among stocks market investors'. Similarly, expanding body of research (Carter [2]; Chen [3]; Nikkinen [7]; Kollias [10]; Papakyriakou [14], et al), have investigated the impact of terrorist attacks to 
conclude that such exogenous shocks can send panic and fear among international investors. Chen and Siems [3], Nippani and Washer [8] show that pandemic effects have similar impact on capital markets as terrorist attacks.

This paper contributes to existing literature by filling the missing gap on assessing the early impact of COVID-19 on stock markets of countries where the epidemic initially started, and investigating their behavior as per reaction to each other's behavior, and duration of the effects of the shock.

The interactive association between these stock markets is important for investors as well as for policy-makers in these countries. Increasing departure of stock prices from their fundamental driver, that is the common economic bonds linking these markets, implies increasing risk for investors in these stocks. The results in this paper can help us understand how these markets can react to common shocks that hit the global economies, and to comprehend the magnitude and scale of future pandemic crisis on major Asian capital markets.

\section{MATERIALS AND METHODS}

Markov-switching models (MSM) are extensively applied in finance, business and economics to capture switching behavior of capital markets and economic growth at periods of shocks (Garcia and Perron [4]; Kim, Nelson and Startz [9]; Guidolin [5; 6], Onour and Sergi [13]; Krolzig H.-M. [11], and on infectious disease outbreak detection (Lu [13], et al.).

MSM models are used for series displaying transition over a finite set of unobserved states, allowing the process to behave differently in each state. The transition time from one state to another and its duration is considered random. For example, these models can be used to indicate the process that controls the time at which stock markets respond to unexpected shock and duration under different states.

Consider the series $z_{t^{\prime}}$ where $t=1,2, \ldots . . T$, is characterized by two states as in the following :

state 1: $z_{t}=\mu_{1}+e_{t}$

state $2: z_{t}=\mu_{2}+e_{t}$

Where $\mu_{1}$ and $\mu_{2}$ are the constant terms in state 1 and state 2 , respectively. $e_{\mathrm{t}}$ is a white noise error term with variance $\sigma^{2}$. The two states model shifts in the intercept term, and if the time of switches is known, the above model can be stated as

$$
z_{\mathrm{t}}=s_{\mathrm{t}} \mu_{1}+\left(1-s_{\mathrm{t}}\right) \mu_{2}+e_{\mathrm{t}}
$$

Where $s_{\mathrm{t}}$ is 1 if the process in state 1 and 0 otherwise. The above model can be estimated using dummy variables and Ordinary Least Square (OLS) estimation technique. But in our case because we don't know in which state is the process at any time and therefore $s_{t}$ is not observed then we cannot use OLS with dummy variables.

As a result, Markov-switching regression models (MSRM) designed to allow the parameters to change over the unobserved states. In the simplest form, we can state the MSRM as statedependent constant term:

$$
y_{\mathrm{t}}=\mu_{\mathrm{st}}+e_{\mathrm{t}}
$$


Where $\mu_{\mathrm{st}}$ is the parameter of interest; $\mu_{\mathrm{st}}=\mu_{1}$ when $s_{\mathrm{t}}=1$ and $\mu_{\mathrm{st}}=\mu_{2}$ when $s_{\mathrm{t}}=2$

Even though it is difficult to specify with certainty in which state the process lies at any point of time, but the probabilities of being in each state can be estimated. For that purpose, the transition probabilities in two states process of Markov chain can be stated as $p_{S t S t+1}$. For example, $p_{11}$ denotes the probability of being in state 1 in the next period given that the process is in state 1 in the current period. Similarly, $p_{22}$ indicate the probability of staying in state 2 , while in state 2 in the most recent immediate period. Probability values closer to 1 imply more persistent process which remains at a given state for longer period of time.

Markov-switching regression models allow a quick adjustment after the process change from one state another, and their general specifications can be stated as:

$$
\left.z_{\mathrm{t}}=\mu_{\mathrm{St}}+x_{\mathrm{t}} \alpha+y_{\mathrm{t}} \beta_{\mathrm{St}}\right)+e_{\mathrm{s}}
$$

Where $z_{\mathrm{t}}$ is the dependent variable, $\mu_{\mathrm{st}}$ is the state dependent constant (intercept) term, $x_{\mathrm{t}}$ is the vector of exogenous variables with state-invariant coefficient $\alpha, y_{t}$ is a vector of exogenous variables with state dependent coefficients $\beta_{\mathrm{st}}$ and $e_{\mathrm{s}}$ is independent and identically distributed error term.

\section{RESULTS}

The descriptive statistics in table 1 reveal significant changes in the four stock markets indexes after the outbreak of the virus after February 10, when the news spread in Asia and then to the rest of the world. The mean figures indicate the average daily losses of these markets during February 10 to March 13, and shows the most hardly hit market was Japan's Nikki 225 which sustained about (-263) points in loss, and the highest median (-153) losses and volatility (400). Japan's Nikki 225 reaction to COVID outbreak was even more stronger than the Chinese stock markets, Shanghai and Hong Kong, where the virus initially was detected. The standard deviation and the mini/max statistics show Nikki 225 and Hong Kong stock markets were the most volatile as losses in these two markets reached record levels of (-1128) and (-648) respectively. The numbers in the table also reveal that Shanghai and Korea stock markets are the most linked to each other, as the response of these two markets are almost identical in most statistics in the table, including the mean losses, volatility, skewness, and the mini/max statistics as well as the sum point losses. The figures 1-5, also reveal the association between these markets.

Table 1

Descriptive statistic of daily change

\begin{tabular}{|l|c|c|c|c|}
\hline & Shanghai & Hong Kong & Japan & Korea \\
\hline mean & -4.26 & -11.63 & -263.93 & -3.85 \\
\hline median & -3.54 & 18.75 & -153.17 & -0.78 \\
\hline Std.dev & 49.36 & 322 & 400 & 33.15 \\
\hline skewness & -0.33 & -0.06 & -0.74 & -0.38 \\
\hline
\end{tabular}




\begin{tabular}{|l|c|c|c|c|}
\hline $\min$ & -111 & -648.69 & -1128.58 & -83.8 \\
\hline $\max$ & 90.63 & 706.95 & 229.06 & 62.3 \\
\hline sum & -110.85 & -302.46 & -6862 & -100 \\
\hline
\end{tabular}

Figures 1-3 reveal that based on stock markets reactions the period from the virus outbreak (February-10) to the second week of March can be segmented into two different states. The first state reveal the time period when the news of the pandemic announcement linked with a great deal of hope that China will be able to contain the virus spread, but soon after it became apparent that the virus has already spread to the rest of the world and may cause world economic downfall due to social containment and business lock out the second state started and governments in Asia and elsewhere pledged fiscal stimulus to avoid economic recession that feed capital markets collapse. These two states can be viewed from the plots of stock price changes included in the figures below.

Figure 1 indicate Hong Kong and Japan stock markets were closely linked to each other in the first state period, but then digressed from each other in the second state, which started from the first week of March.

1000,00

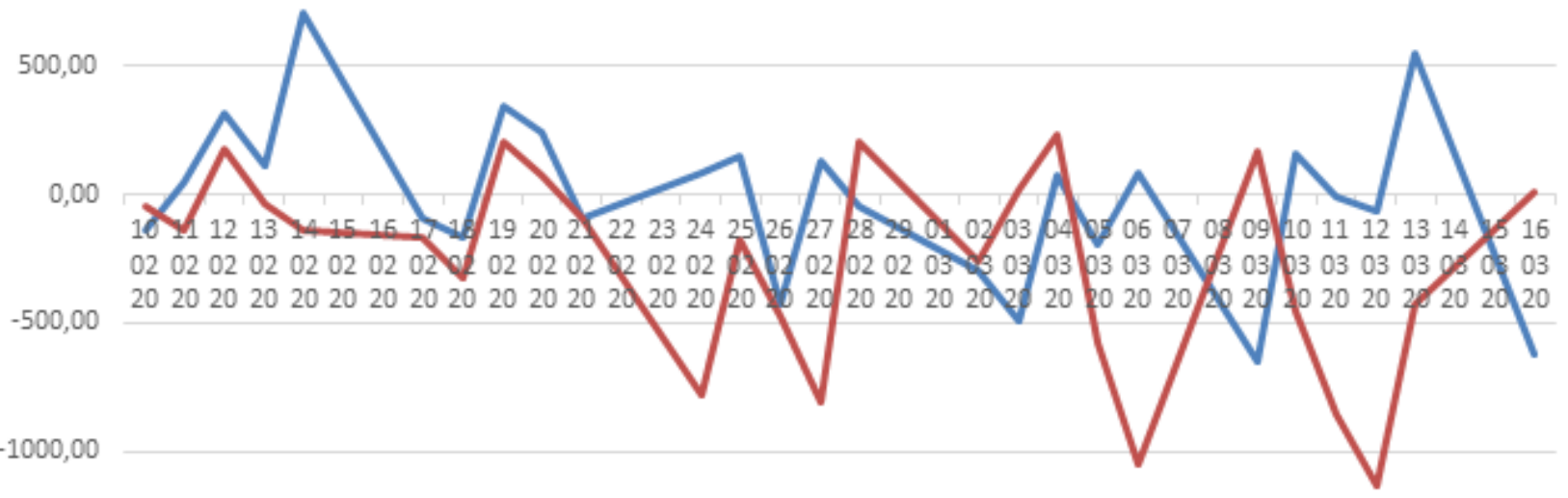

$-1500,00$

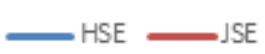

Figure 1 Hong Kong (HSE) and Japan (JSE) stock prices fluctuations

Figure 2 show the behavior of Korean stock market to price change in Shanghai stock market in the two states period. It is apparent that change in Shanghai composite index and Korea stock prices were very closely associated in the first state period, as indicated by the systematic movements, but diverged from each other also by the first week of March, as in the case of figure 1.

Price fluctuations of Shanghai and Hong stock prices in figure 3, also reveal close association of the two markets in the first period (state 1), despite the higher volatility of Hong Kong stock price movements, compared to Shanghai stock price fluctuations. However, in state two which start from the end of the first week of March, the two markets started decoupling behavior (figures 1 and 2). 
150,00

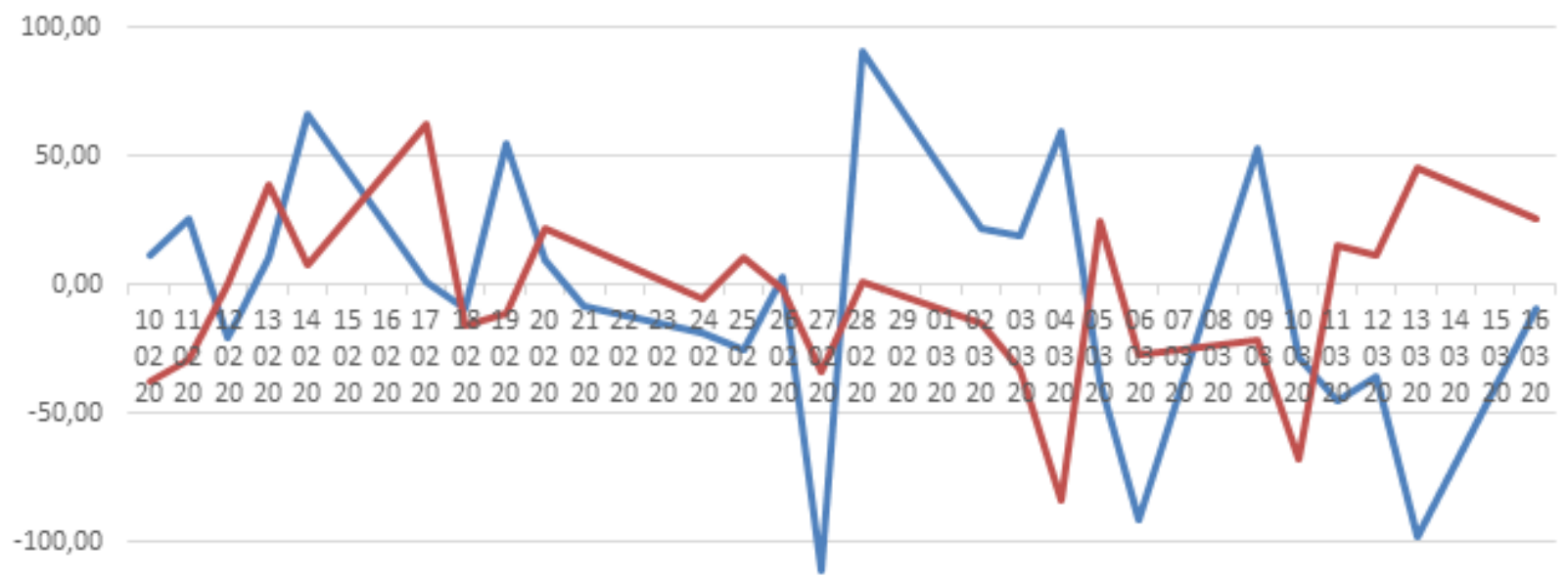

$-150,00$

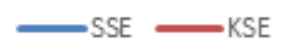

Figure 2 Shanghai and Korea stock prices changes

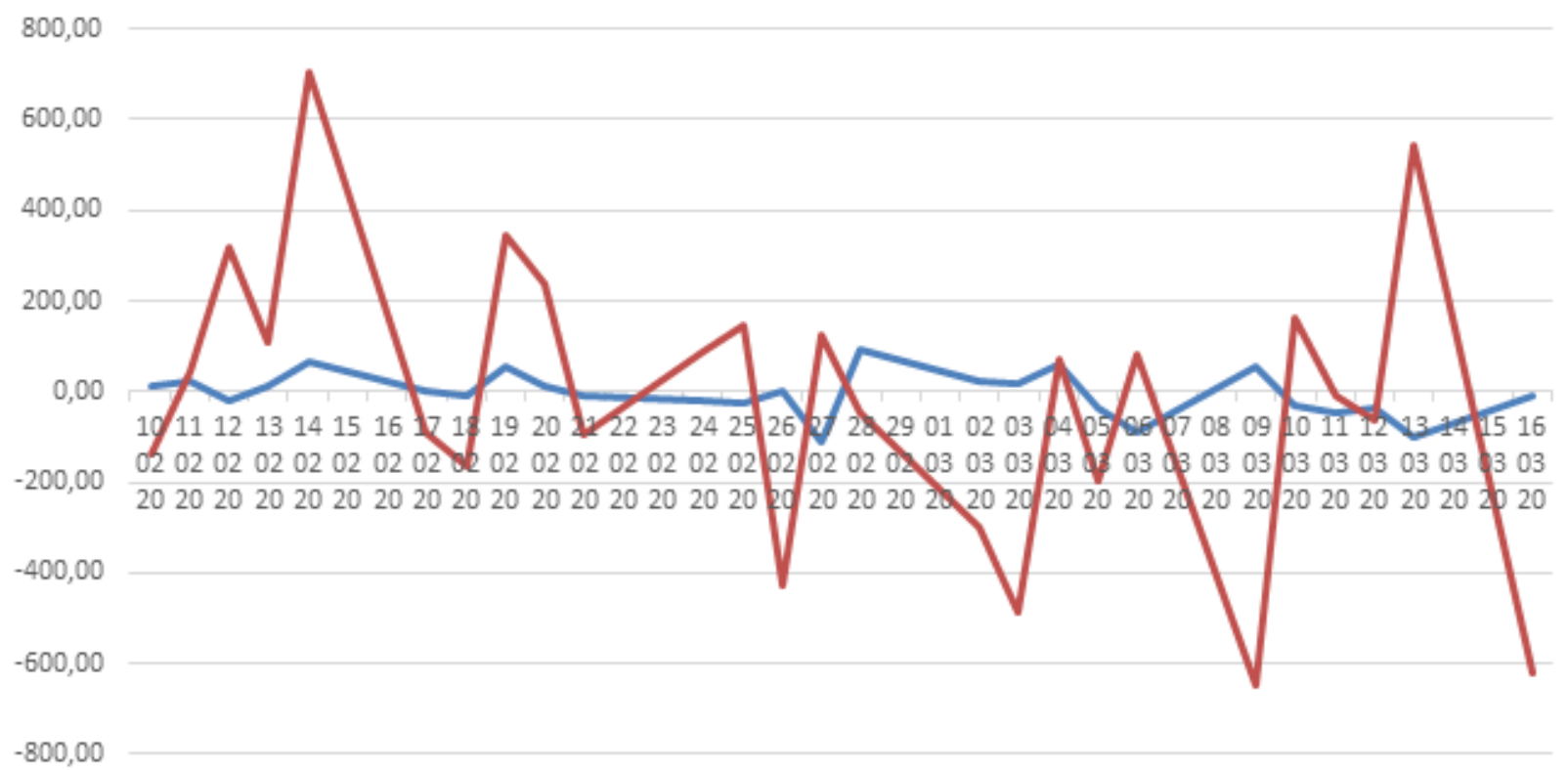

Figure 3 Shanghai and Hong Kong stock prices fluctuations

Figure 4 shows the behavior of Shanghai and Japan stock prices movements in the two states, and indicate that there is no clear (or significant) decoupling effect of the two markets, despite the high volatility behavior of Japan stock market compared to Shanghai stock price fluctuations. The behavior of the two markets prices indicate the positive association of the two markets have been maintained thorough out the two states. Figure 4 also indicate, despite the strong belief that the virus outbreak was initiated in main land China, the response of Shanghai composite index was far less than the other markets, in particular Japan stock market which responded more stronger than the rest of the markets. 


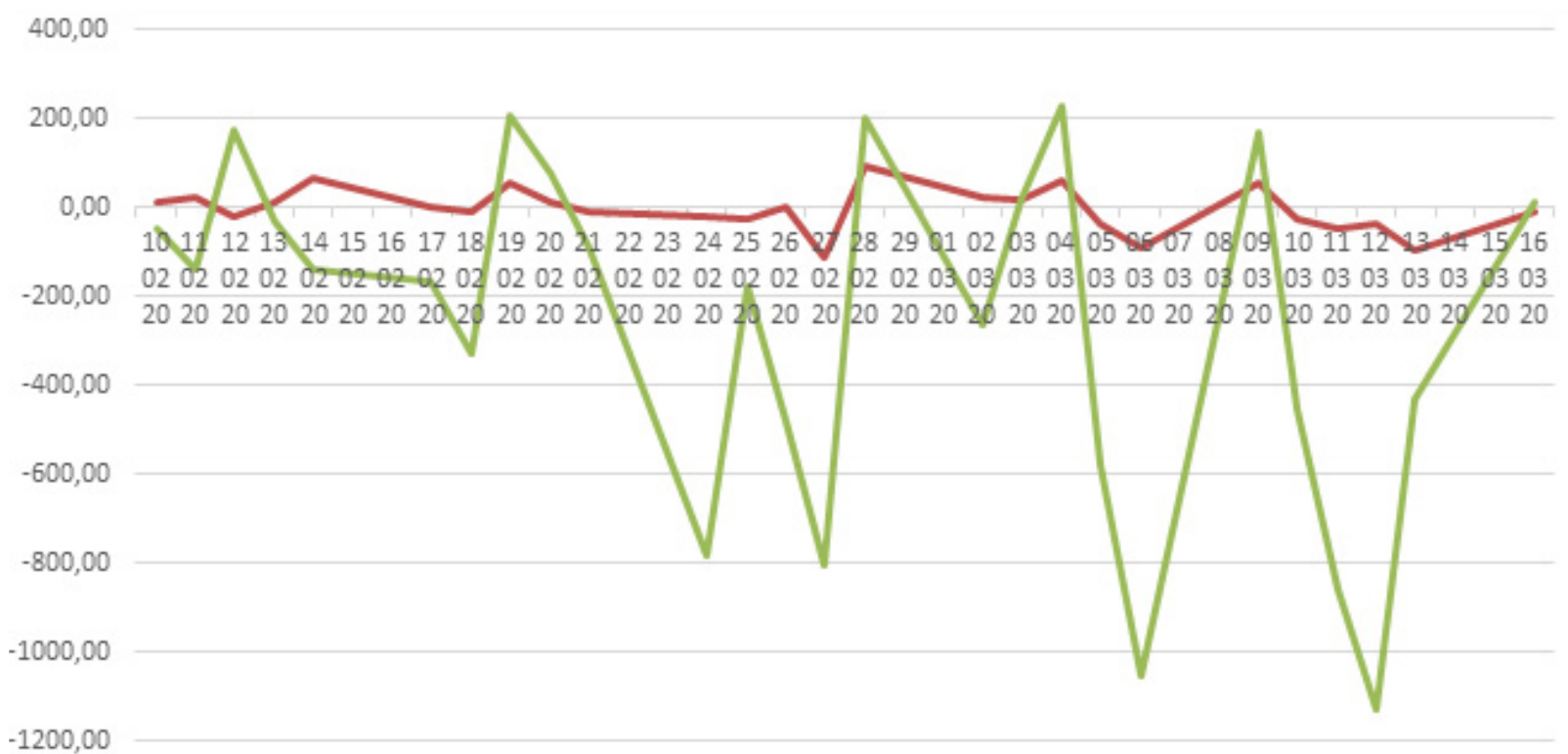

$-1200,00$

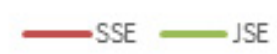

Figure 4 Shanghai (SSE) and Japan (JSE) stock price changes

Tables 2-5 investigate more formally, the dynamics of price change of the four markets using Markov switching dynamic regression (MSDR) that uses change in prices of each market as dependent variable and price change of the other remaining markets as independent variables during COVID-19 outbreak from 2 December 2019 to 13 March 2020. Estimation results of MSDR corroborate with the data plots of the figures 1-4, indicating that there are two distinct states, the state after the announcement of the virus but before realizing it a serious global threat, and the state when the virus outbreak was recognized as a global threat and this was the time when governments comprehended that the pandemic may cause a serious risk to the global economy, as it may roll on uncontrolled for uncertain period of time. Table 2, reveal the behavior of Shanghai stock market reacting to the behavior of the other markets. It shows that in state 1, only Hong Kong and Japan stock markets influence significantly and positively Shanghai stock market, but in state 2, while the impact of the two markets are significant, Japan still linked positively with Shanghai stock price changes, but Hong Kong and Shanghai decouple from each other in state 2 as the coefficient of Hong Kong market become negative. This is exactly what is portrayed in figures 3 and 4 . This implies that after the pandemic outbreak, Hong Kong and Shanghai markets digressed from each other, but Nikki still remained influential to Shanghai stock market. The transition probability p22=0.92, implies that duration of state 2 was about at least two weeks (13 trading days), that is the digression period of Hong Kong market from Shanghai stock market.

Table 3 assesses the behavior of Hong Kong stock market as response to the reaction of the rest of the markets to COVID-19 pandemic effects. It shows in state 1, Hong Kong market was significantly influenced by Korea stock market, but in state 2, started reacting to the news from Shanghai stock market, while diverting from Korea stock market behavior. The impact on Hong Kong market due to COVID-19 pandemic effect initially was significant, even though of short term, lasted only for 3 days, as indicated by the transition probability (p22=0.68). 
Table 2

Shanghai stock market

\begin{tabular}{|c|c|c|c|}
\hline Independent vbls & Coefficient & Std. error & p-value \\
\hline $\begin{array}{l}\text { State 1: } \\
\Delta \text { Hong Kong } \\
\Delta \text { Japan } \\
\Delta \text { Korea } \\
\text { Constant } \\
\text { State 2: } \\
\Delta \text { Hong Kong } \\
\Delta \text { Japan } \\
\Delta \text { Korea } \\
\text { Constant } \\
\text { Transition probabilities: } \\
\text { P11 }=0.37 \\
\text { P12=0.63 } \\
\text { P21 }=0.08 \\
\text { P22 =0.92 } \\
\text { D }(2,2)=13 \text { days } \\
\mathrm{N}=67\end{array}$ & $\begin{array}{c}0.18 \\
0.09 \\
0.62 \\
-38.4 \\
\\
-0.02 \\
0.05 \\
-0.13 \\
9.27\end{array}$ & $\begin{array}{l}0.02 \\
0.03 \\
0.59 \\
10.9 \\
\\
0.01 \\
0.01 \\
0.13 \\
3.63\end{array}$ & $\begin{array}{c}0.000^{*} \\
0.006^{*} \\
0.29 \\
0.000^{*} \\
0.07 \\
0.000^{*} \\
0.34 \\
0.01^{*}\end{array}$ \\
\hline
\end{tabular}

Table 3

Hong Kong SE

\begin{tabular}{|c|c|c|c|}
\hline Independent vbls & Coefficient & Std. error & $p$-value \\
\hline $\begin{array}{l}\text { State } 1: \\
\Delta \text { Shanghai } \\
\Delta \text { Japan } \\
\Delta \text { Korea } \\
\text { Constant } \\
\text { State } 2: \\
\Delta \text { Shanghai } \\
\Delta \text { Japan } \\
\Delta \text { Korea } \\
\text { Constant } \\
\text { Transition probabilities: } \\
\text { P11 }=0.26 \\
\text { P12 }=0.74 \\
\text { P21 }=0.32 \\
\text { P22 }=0.68 \\
\text { D }(2,2)=3 \text { days } \\
N=67\end{array}$ & $\begin{array}{c}-3.96 \\
-0.17 \\
6.68 \\
-198 \\
\\
2.48 \\
0.02 \\
-0.75 \\
78.9\end{array}$ & $\begin{array}{c}2.42 \\
0.29 \\
3.46 \\
129.5 \\
\\
0.83 \\
0.12 \\
1.83 \\
46.6\end{array}$ & $\begin{array}{c}0.10 \\
0.56 \\
0.05^{* *} \\
0.12 \\
\\
0.000^{*} \\
0.82 \\
0.67 \\
0.09\end{array}$ \\
\hline
\end{tabular}

Results in table 4, reveal reaction of Korea stock exchange to responses of the other three markets, and indicate that Korea stock exchange was not showing any signs of being significantly influenced by any market in the group in the two states. The response of Japan stock exchange, in table 5 to the behavior of the other three markets, indicate that Nikki was strongly associated with Shanghai stock exchange in state 1 , but showed decoupling effect from all three markets in state 2 . The transition probability p22=0.99, indicate the duration of state 2 , which reflect its reaction to the behavior of the other markets expected to last at least about three months (100 days) from the start of state 2 , that is the beginning of June-2020. 
Table 4

Korea SE

\begin{tabular}{|c|c|c|c|}
\hline Independent vbls & Coefficient & Std. error & $\mathrm{p}$-value \\
\hline 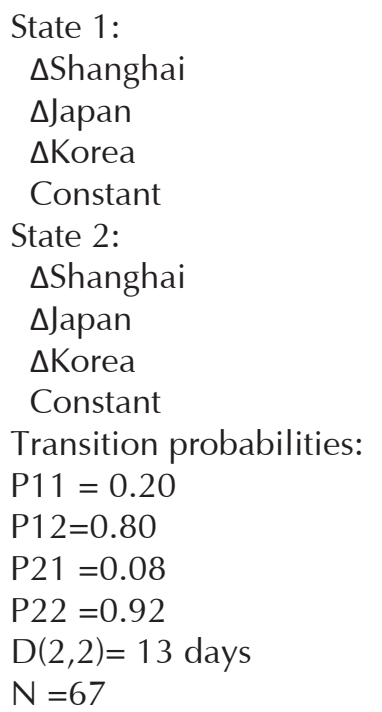 & $\begin{array}{c}0.04 \\
-0.05 \\
-0.92 \\
-5.95 \\
\\
0.002 \\
0.001 \\
-0.028 \\
1.52\end{array}$ & $\begin{array}{c}0.02 \\
0.09 \\
0.57 \\
18.8 \\
\\
0.01 \\
0.01 \\
0.06 \\
3.2\end{array}$ & $\begin{array}{l}0.11 \\
0.55 \\
0.11 \\
0.75 \\
\\
0.83 \\
0.89 \\
0.67 \\
0.63\end{array}$ \\
\hline
\end{tabular}

Table 5

Japan

\begin{tabular}{|c|c|c|c|}
\hline Independent vbls & Coefficient & Std. error & p-value \\
\hline $\begin{array}{l}\text { State } 1: \\
\Delta \text { Shanghai } \\
\Delta \text { Japan } \\
\Delta \text { Korea } \\
\text { Constant } \\
\text { State } 2 \text { : } \\
\Delta \text { Shanghai } \\
\Delta \text { Japan } \\
\Delta \text { Korea } \\
\text { Constant } \\
\text { Transition probabilities: } \\
\text { P11 = } 0.96 \\
\text { P12=0.04 } \\
\text { P21 }=0.01 \\
\text { P22 }=0.99 \\
D(2,2)=100 \text { days } \\
N=67\end{array}$ & $\begin{array}{c}0.28 \\
6.96 \\
-0.09 \\
-268 \\
\\
-0.03 \\
1.01 \\
-2.41 \\
5.42\end{array}$ & $\begin{array}{c}0.22 \\
1.18 \\
1.78 \\
63 \\
\\
0.11 \\
0.83 \\
1.52 \\
33.4\end{array}$ & $\begin{array}{c}0.21 \\
0.000^{*} \\
0.95 \\
0.000^{*} \\
0.75 \\
0.22 \\
0.11 \\
0.87\end{array}$ \\
\hline
\end{tabular}

*Significant at $1 \%$ significance level

${ }^{* *}$ significance at $5 \%$ significance level

\section{DISCUSSION AND CONCLUSIONS}

This paper investigates the impact of COVID-19 pandemic on stock markets behavior in major Asian stock markets, including Shanghai, Hong Kong (SEHK), Japan's Nikkei 225, and Korea Stock price index (kospi), using Markov switching dynamic regression (MSDR) that uses stock price return of each market as dependent variable and price returns of the remaining 
markets as independent variables during COVID-19 outbreak from December-2-2019 to 13-March- 2020. Estimation results of MSDR, indicate there are two distinct states, the state at the announcement of the virus news but before realizing that it may become serious global threat, and the state when the virus outbreak was realized as a global problem and subsequent governments comprehension that the pandemic may cause a serious risk to the global economy, as it may roll on uncontrolled for unknown period of time. Results in the study reveal that Shanghai stock market in state 1, was positively and significantly reacted to Hong Kong and Japan stock price behavior, but in state 2, while the impact of the two markets was still significant on Shanghai stock exchange, Nikkei 225 remained a strong driver of Shanghai stock price changes, but fluctuation in Hong Kong stock price showed decoupling evidence as its coefficient become negative. This implies that after the pandemic outbreak, Hong Kong and Shanghai markets digressed from each other, but Nikkei still remained influential to Shanghai stock market. The transition probability p22 $=0.92$, implies that duration of state 2 was at least two weeks (13 trading days), that is the digression period of Hong Kong market from Shanghai stock market.

However, the behavior of Hong Kong stock market as response to the reaction of the rest of the markets to COVID-19 pandemic effects, indicate in state 1, Hong Kong market was significantly influenced by Korea stock market, but in state 2, started reacting to the news from Shanghai stock market, and decoupling from Korea stock market price changes. The transition probability $(\mathrm{p} 22=0.68)$ reveal that the digression from Shanghai stock market due to COVID-19 pandemic effect was short term, lasted only for 3 days.

Results in the paper also reveal reaction of Korea stock exchange to responses of the other three markets, and indicate that Korea stock exchange was not showing any signs of significant influence by any other market in the group in the two states. The response of Japan stock exchange, to the behavior of the other three markets, indicate Nikkei was strongly associated with Shanghai stock exchange in state 1, but showed decoupling effect from all three markets in state 2 . The transition probability $\mathrm{p} 22=0.99$, indicate the duration of state 2 , which reflect its reaction to the behavior of the other markets expected to last for three months (100 days) from the start of state 2, that is until the beginning of June-2020.

\section{REFERENCES}

1. Burch, T., Emery, D., \& Fuerst, M. (2016). Who Moves Markets in a Sudden Marketwide Crisis? Evidence from 9/11. Journal of Financial and Quantitative Analysis, 51(2), $463-$ 487. doi:10.1017/S0022109016000211

2. Carter, David A., \& Betty J. Simkins (2004). The Market's Reaction to Unexpected, Catastrophic Events: The Case of Airline Stock Returns and the September 11 th Attacks. The Quarterly Review of Economics and Finance, 44 (4), 539-558.

3. Chen, Andrew H., \& Thomas F. Siems (2004). The Effects of Terrorism on Global Capital Markets. European Journal of Political Economy, 20 (2), 349-366. 
4. Garcia, R., \& P. Perron (1996). An analysis of the real interest rate under regime shifts. Review of Economics and Statistics, 78, 111-125.

5. Guidolin, M. (2011a). Markov switching in portfolio choice and asset pricing models: A survey. In Advances in Econometrics, 27B. Missing Data Methods: Time-series Methods and Applications, ed. D. M. Drukker, 87-178. Bingley, UK: Emerald. DOI: 10.1108/ S0731-9053(2011)000027B005.

6. Guidolin, M. (2011b). Markov Switching Models in Empirical Finance, Drukker, D.M. (Ed.) Missing Data Methods: Time-Series Methods and Applications (Advances in Econometrics, Vol. 27 Part 2), Emerald Group Publishing Limited, Bingley, pp. 1-86. https://doi.org/10.1108/S0731-9053(2011)000027B004

7. Nikkinen, Jussi \& Omran, Mohammad M. \& Sahlstrom, Petri \& Aijo, Janne (2008). Stock returns and volatility following the September 11 attacks: Evidence from 53 equity markets. International Review of Financial Analysis, 17(1), 27-46.

8. Nippani, Srinivas, \& Kenneth M. Washer (2004). SARS: A Non-event for Affected Countries' Stock Markets? Applied Financial Economics, 14 (15), 1105-1110.

9. Kim, C.-J., C. R. Nelson, \& R. Startz. 1998. Testing for mean reversion in heteroskedastic data based on Gibbs-sampling-augmented randomization. Journal of Empirical Finance 5, 131-154.

10. Kollias, Christos, Efthalia Manou, Stephanos Papadamou, \& Apostolos Stagiannis (2011). Stock Markets and Terrorist Attacks: Comparative Evidence from a Large and a Small Capitalization Market. European Journal of Political Economy, 27 (S1), S64-S77.

11. Krolzig, H.-M. (1997). Markov-Switching Vector Autoregressions: Modelling, Statistical Inference, and Application to Business Cycle Analysis. New York: Springer.

12. Lu, H.-M., Zeng, D., \& Chen, H. (2010). Prospective infectious disease outbreak detection using Markov switching models. IEEE Transactions on Knowledge and Data Engineering, $22,565-577$.

13. Onour, I.A. \& Sergi, B.S. (2010). GCC stock markets: How risky are they? Int. J. Monetary Economics and Finance, 3 (4), 330-337.

14. Papakyriakou, Panayiotis, Athanasios Sakkas, \& Zenon Taoushianis (2019). The Impact of Terrorist Attacks in G7 Countries on International Stock Markets and the Role of Investor Sentiment. Journal of International Financial Markets, Institutions and Money, $61,143-160$.

15. Qing He, Junyi Liu, Sizhu Wang \& Jishuang Yu (2020). The impact of COVID-19 on stock markets. Economic and Political Studies, 8 (3), 275-288, DOI: 10.1080/20954816.2020.1757570

16. The Economist. 2020a. "Spread and Stutter. 29 February. Available at: https://www. economist.com/financeand-economics/2020/02/27/markets-wake-up-with-a-jolt-tothe-implications-of- COVID-19 (accessed 20 May 2021)

17. The Economist. 2020b. Sneezy Money. 7 March. Available at: https://espresso.economist. com/b0b9da81cf357c8884a06de8ef72bea0 (accessed 20 May 2021) 
18. The Economist. 2020c. The Right Medicine for the World Economy. 7 March. Available at: https://www.economist.com/leaders/2020/03/05/the-right-medicine-for-the-worldeconomy (accessed 20 May 2021)

19. The Economist. 2020d. Tracking the Economic Impact of COVID-19 in Real Time. 14 March. Available at: https://www.economist.com/united-states/2020/03/14/trackingthe-economic-impact-of COVID-19-in-real-time (accessed 20 May 2021)

\section{INFORMATION ABOUT THE AUTHOR}

Ibrahim A. Onour (Sudan, Khartoum) - Professor, School of Management Studies. University of Khartoum. E-mail: onour@uofk.edu. Scopus ID: 6506520131. ORCID ID: 0000-0002-9967-6873

\section{(c) (i)}

Available: https://statecounsellor.wordpress.com/2021/05/30/onour/

Received: Jan 30, 2021 | Accepted: Apr 14, 2021 | Published: Jun 1, 2021

Editor: Mohamed R. Abonazel, PhD in Statistics and Econometrics. Cairo University, EGYPT

Copyright: (C) 2021 Onour, I. A. This is an open access article distributed under the terms of the Creative Commons Attribution License, which permits unrestricted use, distribution, and reproduction in any medium, provided the original author and source are credited.

Competing interests: The authors have declared that no competing interests exist. 